\title{
ONLINE MARKETING AND CONSUMER BUYING BEHAVIOUR OF ELECTRONIC PRODUCTS IN THE NORTH CENTRAL ZONE OF NIGERIA
}

\author{
Dr. Hanmaikyur Tyopine ${ }^{1 *}$ \\ *lDepartment of Business Administration, Federal University of Agriculture, Makurdi, Nigeria.
}

*Corresponding Author: -

\begin{abstract}
: -
This study examined effects of online marketing and consumer buying behaviour of electronic products in the north central zone of Nigeria. The population of this study comprised online marketers and online consumers in the seven states in north central zone of Nigeria. Because the population is infinite, a sample of 385 respondents were taken from marketers and the online consumers. Information was obtained from the respondents using a structured questionnaire. The data collected were analyzed using descriptive statistics such as frequency, simple percentage and the relationship between the variables of the model was tested using multiple linear regression analysis. The result of the regression analysis indicates that a negative relationship exist between perceived risk on consumer (PRK) and consumer buying behavior of electronic products in the north central zone of Nigeria $(\mathrm{CBHV})$ and the relationship is not statistically significant $(p>0.05)$. A positive relationship exist between perceived enjoyment (PEN) and consumer buying behavior of electronic products in the north central zone of Nigeria $(C B H V)$ and the relationship is statistically significant $(p<0.05)$. Perceived ease of use (PEU) was positively related to consumer buying behavior of electronic products in the north central zone of Nigeria $(\mathrm{CBHV})$ and the relationship is statistically significant $(p<0.05)$. Perceived usefulness $(P U F)$ was negatively related to consumer buying behavior of electronic products in the north central zone of Nigeria $(C B H V)$ and the relationship is not statistically significant ( $p>0.05$ ). A positive relationship exist between perceived convenience (PCN) and consumer buying behavior of electronic products in the north central zone of Nigeria (CBHV) and the relationship is statistically significant $(p<0.05)$. It was concluded that majority of the respondents who patronize online shopping adopt that because of the convenience and time saving factor they obtain from it. It was recommended among others that owners of online marketing platform should ensure that they make their website dynamic and user friendly so as to attract customers who will derive comfort and satisfaction transacting from the comfort of their homes.
\end{abstract}

Keywords: - Marketing, Online, Consumer, Behaviour, Electronic, Products, Nigeria 


\subsection{INTRODUCTION}

Companies today face the challenge of increasing competition, expanding markets, and rising customer expectations. To remain competitive, companies must improve their business practices and employ new social media marketing channels, the same channels where the mass of customers nowadays daily visit. This study was carried out to find out how Finnish companies utilise social media and the Internet in Business-to-Consumer (B2C) marketing and visibility improving. This goal was accomplished through a literature review and analyzing acquired questionnaire data that was collected among Finnish companies in spring 2012 Online marketing is a relatively new business channel, which entails selling and buying goods and services using a technology channel, like the World Wide Web or Internet. It is a state of art technology that is comprised of hardware, software and network equipment whereby each of the components works as a single system bringing people closer. This new technology has been used and implemented worldwide so that people can be connected to each other, in both personal and business matters, by just clicking a mouse anywhere and at any time. Being easy to use and inexpensive, online marketing has been rapidly growing each year (Chang, Cheung, and Lai, 2004; Yang and Lester, 2004) and; is currently utilized for shopping, information search, bills payment, news, weather reports, and online games (Siriporn, 2007).

Meanwhile online marketers developed and introduced new internet-based marketing aspect and as a result a new world for marketing was born. Internet marketing as a part of e-marketing led to the development of websites for business. Internet $\mathrm{m}$ a $\mathrm{r} \mathrm{k}$ e $\mathrm{t}$ i $\mathrm{g}$ in recent decade has very huge movement forward and companies all over the world use internet for advertisements or for corporate promotion activities. Besides, not many companies fully utilize their system with recruiting the power of Internet in business as new channel of doing transactions (Kiang, Raghu, and Shang, 2000). Also media consumption is changing too. The rise of convergent technology and social media is growing. Consumers online are growing rapidly because the internet makes their lifestyle easier as they tend to shop around more because they have access to several other points of information. They use the internet to research before committing to purchase and are early adopters of technology because they have a world view (Ugonna, Okolo, Nebo, \& Ojieze, 2017) cited (Asoto, 2010).

Consumer behaviour is the study of how individual customers, groups or organizations select, buy, use, and dispose ideas, goods, and services to satisfy their needs and wants. It refers to the actions of the consumers in the marketplace and the underlying motives for those actions. Consumer behaviour blends elements from psychology, sociology, social anthropology, marketing and economics, especially behavioural economics. Consumer behavior towards online shopping is a field of interest for both scholars and professionals because internet has greatly influenced the preferences and buying pattern of customers. Internet is changing the way consumers shop and buy goods and services, and has rapidly evolved into a global phenomenon (Asoto, 2010). Many companies have started using the Internet with the aim of cutting marketing costs, thereby reducing the price of their product and service in order to stay ahead in highly competitive markets. Companies also use the Internet to convey, communicate and disseminate information to sell the product, to take feedback and also to conduct satisfaction surveys with customers. Customers use the internet not only to buy the product online, but also to compare prices, product features and after sale service facilities. Scholars and practitioners of electronic commerce constantly strive to gain an improved insight into consumer behavior in cyberspace. It is a common knowledge that virtually all organizations in Nigeria have online presence and internet access. Their goods and services are displayed online similarly; this is primarily due to the high number of cybercafés that offer internet access to all and sundry for a fee. Asoto, (2010) opined that, in the Nigerian landscape, marketers and their clients are becoming aware of the need and underlying effects of online marketing via the internet; the trend has started to build where agencies ignorantly advise clients to use banner adverts and display adverts for campaign on Facebook, Yahoo, local news and entertainment sites, as opposed to looking critically at what the clients want to achieve and advising them on all the various digital marketing platforms available and what each of them can achieve and how to use them (Asoto, 2010).

In order to gain competitive edge in the market, marketers need to know the consumer behavior in the field of online marketing. So it is important to analyze and identify the factors which influence consumers to shop online in order to capture the demands of consumers. Despite the growth of internet in Nigeria, studies have been carried out in online marketing on consumer buying behavior. However, a few (if any) of these studies carried out locally have appreciated the factors or effects of appropriate and efficient coordination as well as all the tools of online marketing and consumers buying behaviour of electronic products which include Perceived Risk (PR), Perceived Enjoyment (PE), Perceived Ease of Use (PEOU), Perceived Usefulness (PU) and Perceived Convenience (PC). The problem in business to consumer (B2C) stated by the author is, what drives consumers to shop online and their perception towards online marketing is what we need to explored in this study. This is the gap found in the literature.

Furthermore, In order to shop online, one must have access to an internet enabled computer and modern or mobile device and a suitable mode of payment. These prerequisites are available in Nigeria even in North Central Zone and are thus expected to be ideal users of online shopping platforms. Despite the availability and thriving of internet access in Nigeria, North Central Zone is seen to take a slow pace in making online purchases. Therefore, North Central Zone is not an exception and thus the justification for the study.

The general purpose of this study will be to investigate the effects of online marketing and consumer buying behaviour of electronic products in the north central zone of Nigeria. The specific objectives of this study will include; To determine the effect of perceived risk on consumer buying behavior of electronic products in the north central zone of Nigeria. To examine the effect of perceived enjoyment on consumer buying behavior of electronic products in the north central zone of Nigeria. To evaluate the effect of perceived ease of use on consumer buying behavior of electronic products in the north central zone of Nigeria. To assess the effect of perceived usefulness on consumer buying behavior of electronic 
products in the north central zone of Nigeria. To evaluate the effect of perceived convenience on consumer buying behavior of electronic products in the north central zone of Nigeria.

\subsection{Literature Review Theoretical Review The Theory of Planned Behavior}

This theory was built on the Theory of Reasoned Action in 1985 (Ramus and Nielsen, 2005) by adding one construct to it; Perceived Behavioral Control. The new construct was added to provide a better prediction of the user's performance behavior. It was developed to predict individual intention behavior of technology adoption. It has also been validated by previous studies (Cook, Kerr, and Moore, 2002; George, 2004; Limayem, Khalifa, and Frini, 2000; Ramus and Nielsen, 2005; Shim, Eastlick, Lotz, and Warrington, 2001; Zhang, Prybutok, and Strutton, 2004 and is good for predicting consumers' intent behavior in marketing and consumer behavior areas, while the Technology Acceptance Model is good for finding user acceptance in the technology area. It is also more developed than other models, such as the Technology Acceptance Model and the Theory of Reasoned Action. It was developed by Ajzen (Ajzen, 1991; George, 2004; Limayem et al, 2000).

In addition, the Theory of Planned Behaviour (TPB) has been widely used in many articles with a focus on purchase intention as well as on the Internet shopping. It is suitable for finding consumers' behavioural intentions based on three independent variables. As you can see in the below figure attitude towards behavior and subjective norm are basically the factors that influence buyers intention. Attitude towards the behaviour, subjective norm and perceived behavioural control.

On the other side perceived behavioral control actually moves towards the actual behavioral by influencing the intention. This is in relationship with objectives one and two, individual perception can be perceived either positively or negatively which result to either perceived risk and/or perceived enjoyment from the consumer.

\section{Conceptual Review \\ Concept of Online Marketing}

Online marketing (e-marketing) refers to the strategic process of distributing, promoting, pricing products, and discovering the desires of customers using digital media and digital marketing. E- marketing goes beyond the Internet and also includes mobile phones, banner ads, digital outdoor marketing, and social networks (Pride \& Ferrell, 2012.) Because of the fierce competition on the Web for the attention of the potential buyers, it takes enormous marketing expenditures from the E-marketers to set themselves out from the crowd, get visitors to their sites and get them actually make a purchase (Hoffman \& Novak, 2000).

Advertising in the Internet plays an extremely important role in e-commerce. The most important reasons for this are: online ads can reach a large number of consumers, ads are easily updated, they can contain text, audio or animation, and online ads are frequently cheaper than traditional ads (Turban et al., 2010). The major advantages of using the Internet for marketing are precise targeting, interactivity, rich media, cost reduction, efficiency and customer acquisition. In addition, the Internet is the fastest growing communication medium by far. Almost from the beginning of the Internet one of the most important new capabilities has been its bi-directionality, when compared to previous mass communication technologies, (Dellarocas, 2003). When consumers are allowed to communicate bidirectionally, it may make consumers think of the sites as more accessible, which may also be beneficial for building and sustaining relationships (Yoon et al., 2008). Now social media has amplified the power of consumer-to-consumer conversations in the marketplace by enabling one person to communicate with literally hundreds of thousands of other consumers quickly and with relatively little effort. However, companies cannot directly control these conversations (Mangold \& Faulds, 2009.) One of the weaknesses of traditional marketing is that the advertisers know nothing (e.g., on TV - or print marketing) or only very little (direct mail marketing) of about the recipients (Turban et al., 2010). In online marketing, the structure of online communications allows publishers and advertiser networks to learn considerably more about online users than has been possible with traditional media. Companies can use this data for their own benefit and associate products with the customers who were buying them. In Internet, online media or their ad networks typically know for certain whether an individual is viewing their site at a certain time. In addition, individual websites may have detailed information on registered users and this information they can also use for advertising. The platform can determine the time of day and location of the view and may also be able to determine certain characteristics of the viewer. For example, search engines know the keywords a user requested, and publishers know the content of the page at which the user is looking. Both may know recent search or browsing behavior. Advertisers can target their messages to those consumers for whom the messages are most relevant and who are most likely to buy as a result of receiving this message (Evans, 2009.) Concept of Consumer Buying Behaviour

Grimsley (2015), states that consumer buying behavior is the sum total of a consumers' attitudes, preferences, intentions, and decisions regarding the consumers' behavior in the market place when purchasing a product (goods) or service. Consumer buying behavior is an art and science of knowing needs and wants of consumers, and developing an understanding on how prospective buyers decide to spend their resources like time, money and efforts during different stages of buying process. Buyer behavior is a study of how individuals make decision to spend their available resources (time, money and effort) on consumption related items (what they buy, why they buy, where they buy, how often they buy and use a product or service), especially the factors related to occupation. With the increasing disposable income population, their per capita consumption of electronic goods and other products is increasing (Venkat, 2015).

Kardes (2002) has defined Consumer behaviour as the study of human response to products or services and the 
marketing of products and services. Consumer behaviour is the behaviour that consumers display in searching for, purchasing, using, evaluating products or services and ideas that they expect will satisfy their needs. Schiffman and Kanuk (2002) assumed consumer behaviour as the buying behaviour of final consumers, individuals and households. Also consumer is the behaviour of the ultimate consumers, those who purchase products for personal or household use, not for business.

Buyer behavior is comparatively new field of study. It is the attempt to understand and predict human activities in the buying role. It has assumed giving importance under the marketing oriented or consumer oriented marketing, planning and management. Buyer behaviour is defined as "all psychological, social and physical behaviour of potential consumers as they became aware of evaluate, purchase, consume and tell others about products and services (Venkat, 2015).

Consumer behavior is the study of individuals, groups, or organizations and the processes they use to select, secure, and dispose of products, services, experiences, or ideas to satisfy needs and the impacts that these processes have on the consumer and society (Kuester, 2012).

\section{Dimensions of Online Marketing Perceived Risk}

Perceived risk is consumer's perceptions of the uncertainty, and advised consequences of buying a product or service. Forsythe and Shi (2003) defined perceived risk in online shopping as the subjectively determined expectation of loss by an Internet shopper. Pavlou (2003) defined perceived risk as consumers' subjective fear of suffering a loss in pursuit of a desired outcome. Perceived risk is a consumer's belief about the potential uncertain negative outcomes from the online transaction (Kim et al., 2008). Perceived risk considered as the main barrier to online shopping.

According to Li and Zhang (2002), perceived risk has a negative and significant influence on consumer buying attitude towards online shopping, for instance e- retailing. They mentioned that, perceived risk is an important element of consumer attitude towards online shopping behavior. There are generally two elements of perceived risk which are associated with the process of online shopping: risk related to the context of online transaction and risk related to the product or service. Perceived Enjoyment Enjoyment in shopping can be two-fold: enjoyment from the product purchased as well as the process of shopping itself. Online shopping like in-store shopping, provided both types of enjoyment and such enjoyment can positively or negatively influence online shopping (Taylor \& Cosenza, 1999). Childers et al (2001) concluded that "enjoyment" results from the fun and playfulness of the online shopping experience, rather than from shopping task completion. The purchase of goods may be incidental to the experience of online shopping. Thus, "enjoyment" reflects consumers' perceptions regarding the potential entertainment of internet shopping.

\section{Perceived Ease of Use}

According to Buton-Jones and Hubona (2005), the ease of learning and becoming skilful at using pervasive technologies, including technologies and interfaces on online shopping sites, were concluded as valid determinants as to what makes a technology easy to use. The work of Selamat et al. (2009) further added that a technology which is perceived to be easier to use than another is more likely to be accepted by users whereas the more complex a technology is perceived to be, the slower will be its rate of adoption.

This is supported by Teo (2001) as the study concluded that a system which is easy to use often requires less effort on the part of users and thereby increases the likelihood of adoption and usage of a particular technology. Other scholars have also found that the perceived ease of use had a positive influence on consumers' attitude in using the Internet to shop online (Bisdee, 2007; Yulihasri \& Daud, 2011).

\section{Perceived Usefulness}

According to McCloskey (2004), the ability to improve shopping performance, shopping productivity, and most importantly, accomplishing shopping goals, were concluded as valid determinants as to what makes consumers' shopping activity a success. This is in line with the findings of Barkhi et al. (2008) as their study suggests that consumers will develop favourable attitudes toward products and/or services that they believe to provide sufficient benefits or attributes toward a solution and negative attitudes toward those that are inadequate. Given this scenario, Kim et al. (2003) argued that online shopping sites which provide functions which aid consumers in making better shopping decisions will be perceived as useful.

\section{Perceived Convenience}

Chiang and Dholakia's study in 2003 found that people are influenced to shop online primarily due to convenience. From the service sector point of view, convenience can be defined as discernment made based on the perceptions over the experience obtained while using the service in terms of level of effort and time required as well as control on the management (Farquhar \& Rowley, 2009).

Meanwhile, in the utilitarian perspective, people are keen to purchase products effectively and in timely fashion with the lowest vexation as possible. The feature of technology-based retail channels that allows consumers to have an extent of flexibility and interactivity more than the conventional retail channels has led to the creation of positive attitude towards the act of purchasing online. This is due to its availability within 24 hours of time and the information can be retrieved from anywhere (Childers et al., 2001). Review of Related Empirical Studies

However, Jayawardhena et al (2003) in their study found that convenience is the second reason on why people buy goods and services online. The findings of Khalifa and Limayem's (2003) study also pointed out that the convenience 
variable does not significantly affect the shoppers' intentions toward shopping online. Smith and Rupp (2003) have argued that the transactions in online shops are very convenient to shoppers but not for some goods such as clothing that shoppers need to touch and try on before buying.

Kim (2004) in his research on consumers' shopping and purchasing behaviour, came to the conclusion that despite the remarkable growth in Internet sales, there was evidence to suggest that there were many consumers shopping with intent to buy at retail websites, but for some reason did not complete the transaction.

Tarinee (2007) in his study aims to identify the influential factors on consumers' purchasing decisions in Bangkok pet retailing business. The scope of the study is based on the profiles of Thai consumers who have been using either products or services from Bangkok pet retailers. The study is quantitative research, using a structured questionnaire to collect the data from 400 consumers who have been using either products or services from Bangkok pet retailers and have pets at presents. The researcher analyzes data variables using percentages, frequencies, means, standard deviations, t-Test, and ANOVA to test hypotheses and answer the research questions. The study identifies independent variables including demographic factors (age, gender, education background, and monthly income), consumer behavior factors (frequency of purchasing and average spending per visit), and marketing mix factors (product, price, place, and promotion). The dependent variable is the consumers' purchasing decisions in Bangkok pet retailing business. The result shows that both demographic factors and marketing mix factors do not have significant relationship with the consumers' purchasing decisions in the Bangkok pet retailing business, while the consumer behavior has a significant relationship with the consumers' behavior in Bangkok pet retailing business.

Chen (2009) extends theory of planned behavior (TPB) by including ten important antecedents as external beliefs to online consumer behavior. The ten antecedents are identified by prior studies, mostly in the areas of management information systems and marketing science. This study is conducted with a survey of 288 college students who have online shopping experiences. The collected survey data is used to test each hypothesis developed in the research model. The results of data analysis confirm perceived ease of use (PEOU) and trust are essential antecedents in determining online consumer behavior through behavioral attitude and perceived behavioral control. The findings also indicate that cost reduction helps the consumer create positive attitude toward purchase. Further, the findings show the effects of two constructs of flow - concentration and telepresence on consumer's attitude. Concentration is positively related to attitude toward purchase, but telepresence likely decreases attitude due to the consumer's possible nervousness or concern about uncertainty in the online environment.

Soonyong Bae, Taesik Lee (2010) investigates the effect of online consumer reviews on consumer's purchase intention. In particular, they examine whether there are gender different in responding to onlineconsumer reviews. The results show that the effect of online consumer reviews on purchase intention is stronger for females than males. The negativity effect, that consumers are influenced by a negative review more than by a positive review, is also found to be more evident for females. These findings have practical implications for online sellers to guide them to effectively use online consumer reviews to engage females in online shopping.

Ayo, Adewoye and Oni (2011) empirically investigate B2C e-commerce in Nigeria system usage using a combination of information system adoption models. An extended Technology Acceptance Model (TAM) with task-technology fit, perceived risk and trust was developed and tested using linear regression. The correlation analysis was carried out to examine the relationship between the constructs. Findings revealed that there are significant relationships between the model variables. Task- technology fit and perceived usefulness have significant relationships with intentions to use, having a correlation coefficient of 0.2623 and 0.2002 respectively. Similarly, the interrelationship among trust, perceived risk, and behavioral intention are significant. The effect of risk on trust was statistically showing that risk is a predictor of trust. Risk has a high significant on trust and trust in turn has low significant effect on behavioral intention. Adding TTF and its relationships to the TAM also fit the data. The relationship between task-technology fit, perceived ease of use, perceived usefulness and intention are significant.

Suresh and Shashikala (2011) investigate the factors influencing customer perceived risk of online shopping in Indian context. Reliability coefficient for the scale was satisfactory and factor analysis generated 6 major factors: Monetary, Performance, Time, Source, Social, and Psychological. Monetary and performance risks have highest mean scores and social and psychological risks being the lowest. Further $T$ test confirmed that all of these factors had significant impact. Weng and Ding, (2012), their paper examined relationship between PEOU, PU, attitude towards online shopping, and consumers' intention to shop online. An associative analysis in the form of a correlation analysis was conducted to test for existence of multicollinearity. Then, multiple regression analyses were performed to test the relationship between the whole set of predictors and the dependent variables under the current study. Factors loading ranged from 0.779 to 0.975 , Cronbach's alpha was calculated for each factor, and each was found reliable $(a=0.960,0.959,0.944$, and 0.954 respectively). These four factors were: perceived ease of use, perceived usefulness, attitude toward online shopping, and intention to shop online. Results showed that consumers' intention to shop online is determined by their attitude towards online shopping. Further, the results highlighted the importance of PEOU and PU of online shopping sites towards consumers' attitude towards online shopping in terms of how easy or effortless and how useful online shopping sites are in creating a favourable shopping environment.

A study conducted by Adil (2013) on consumer behavior towards online shopping of electronics in Pakistan examines how consumers behave while shopping online. Primary data was collected through the questionnaire survey and by emails from personal contacts in two major cities of Pakistan. It was concluded that price, time saving and convenience were identified as important factors which lead to certain buying behavior in online shopping. While the www is rebuilt around people where social circles influence and lead to online buying. 
A survey conducted in Pakistan revealed when a consumer has the mind to purchase electronic goods online, he or she is affected by multiple factors (Sunil, 2014). Bhatt and Bhatt (2012) in their study found that regular buyers are most influenced by ease/attractiveness and service quality of websites while occasional buyers value website security more than other categories of consumers. A study carried out by Delafrooz, et al. (2010) revealed that utilitarian orientation, convenience, price, and a wider selection influenced consumers' attitudes towards online shopping.

Dipti, et al, (2014) examine they four dimensions of online shopping as perceived by consumers in India were identified. The population of this research consisted of online shoppers from Delhi. The sample of the study comprised of 160 online shoppers. Respondents belonged to different age groups, income groups and occupations and have a prior experience in online shopping. A pre-structured questionnaire was used with a 5 point Likert rating scale to measure the factors influencing the respondent's behavior to shop online. The empirical results revealed that only one factor, namely Perceived Risk significantly affected online shopping behavior of consumers in Delhi while Perceived enjoyment, Perceived ease of use and Perceived enjoyment hinders the consumers to shop online.

Jenyo and Soyoyo (2015) seek to understand to what extent the functionality of the infrastructure of the internet and the internet security issues impact consumers' decision to eventually purchase. The survey research used a structured questionnaire to elicit data from selected firms in Lagos State, Nigeria. A reliable Cronbach's Alpha was used to determine the reliability of the questionnaire. The data was analyzed using simple regression while the hypotheses drawn were tested. The findings show that online marketing has impacted consumer purchase decisions in Nigeria firms. There is a significant relationship between consumer purchase decisions and infrastructure of the internet in Nigeria. There also exists relationship between internet security and consumer purchase behaviour. These simply imply that one variable influences the other.

Leyiaro (2015) investigated factors influencing online buying behaviour of Geothermal Development Company (GDC) employees in Nakuru town, Kenya. The target population for the study is employees of Geothermal Development Company based in Nakuru town who were 732 in number. Systematic sampling was used to take a sample of 110 employees. A closed ended survey questionnaire was administered to collect primary data. Statistical Package for Social Sciences (SPSS) and Microsoft excel package was used for data analysis and findings were presented in tables. The findings indicated that perceived risk shared $39.94 \%$ of the variability of online buying behaviour of GDC employees. Similar statistically significant correlation result was arrived at for psychological factors which shared a variability of $28.73 \%$ with online buying behaviour. A medium positive relationship between perceived benefits of online shopping and consumer online buying behavior was established with a shared variability of $2.04 \%$.

Website design had a Pearson correlation coefficient of $r=0.251 p$ (one-tailed) >

0.05 hence it was concluded that there was no statistically significant relationship between website design and consumer online buying behaviour. Muhammad, Muhammad and Chaudhary (2015) investigate the relationship between factors affecting consumer buying behavior towards online shopping. They stated that, online shopping refers to the recent up surging trend of being able to buy what you need while sitting at home. The focus of the research is on the influence of five major variables that were derived from literature

i.e. trust, time, product variety, convenience and privacy, on consumer buying behavior (dependent variable) to determine how consumer buying behavior is reflecting online shopping trends. The study revealed that trust and convenience are greatly impactful on whether people choose to buy online or through brick and mortar stores, while privacy has a lesser influence of buying behavior.

The study of Jadhav and Khanna (2016) explore the factors influencing the online buying behavior of the college students. Convenience sampling method was used to select the sample of 25 college students and qualitative content analysis was used for analyzing the textual content of the depth interview data. The main influencing factors for online shopping were identified as availability, low price, promotions, comparison, convenience, customer service, perceived ease of use, attitude, time consciousness, trust and variety seeking.

Mohammed (2016) examines the acceptance of online shopping and the factors which influence this behavior throughout this country. In his study, SPSS software was used to conduct an analysis on the collected data. Descriptive statistics, Cronbach's Alpha, Pearson's correlation, Factor analysis, missing data, treatment of outer, normality, homoscedasticity, and multicollinearity and multiple regressions were the statistical tools that were conducted. His research investigated the relationship of (TAM) Technology Acceptance Model constructs in online shopping area in one of the developing Arab countries i.e. Jordan. The finding of the study showed that customers' intention to shop online is determined by their attitude towards online shopping. Further, it showed the importance of perceived ease of use and perceived usefulness of online shopping sites to form customers' attitude towards online shopping.

Ugonna, Okolo, Nebo, and Ojieze (2017) examined the influence of efficient online marketing, effective communication, and on-time delivery on the regularity of visits and consumer patronage of the three selected online stores in Owerri, Imo State. It was guided by six research questions and six hypotheses. The sample size was 300 respondents two sets of structured questionnaire were used for data collection. Mean statistics was used to analyze the responses of the research questions, while Z-test analysis was applied to test the hypotheses for this study.

A Statistical Package for Social Sciences (SPSS) software was used to analyse the data. The findings of the study showed that online marketing is a viable marketing communication channel which has significant effect on the regularity of visits and consumer patronage of online stores.

\subsection{Methodology}

This study used the descriptive research is the most used in the marketing field. This is to describe the characteristics of 
certain people, to determine and predict their behavior in a specific situation with a clear research question/problem statement and focused hypotheses. Thus, the descriptive research design used research to describe online marketers' characteristics.

The population of this study will c o m p r is e online marketers and online consumers in the seven states in north central zone of Nigeria; they include Benue, Kogi, Nasaraw, Plateau, Niger, Kwara and FCT Abuja. Out of this overall population, only online marketers and online consumers who at the time of this study are available and have made purchases of electronic devices via the internet, will be use as respondents for this study.

The sample size for this study will come from online marketers and online consumers. The judgmental sampling method will be used to obtain a sample size of 385 respondents from the seven states in the north central zone. 55 respondents will be sampled in each from the seven states in the north central zone. The method of primary data collection will be the use of questionnaire approach.

In this study, the two most common types of validity, which are content and construct validity, was considered. While content validity were carried out through the expert contributions from my supervisors, construct validity was tested with the use of Factor analytical tool that considered Kaiser- Meyer-Olkin (KMO) and Bartlett's Test of Sphericity.

The result of the factor analysis indicates that the result instrument is valid while the reliability of the instrument is 0.898. This shows that the instrument of data collection is valid.

The model specifications for this study is shown below

The implicit function for the model of the study is shown below:

$$
\mathrm{CBHV}=f(\mathrm{PRK}, \mathrm{PEN}, \mathrm{PEU}, \mathrm{PUF}, \mathrm{PCN})-(1)
$$

Where,

$\mathrm{X}_{1}=$ Perceived risk PRK

$\mathrm{X}_{2}=$ Perceived enjoyment PEN

$\mathrm{X}_{3}=$ Perceived ease of use PEU

$\mathrm{X}_{4}=$ Perceived usefulness PUF

$\mathrm{X}_{5}=$ Perceived convenience $\mathrm{PCN}$

$\mathrm{CHBV}=$ Buying behaviour

Explicitly, it is given as shown below:

$b_{0}=$ Constant term

$$
\mathrm{CBHV}=\mathrm{b}_{0}+\mathrm{b}_{1} \mathrm{PRK}+\mathrm{b}_{2} \mathrm{PEN}+\mathrm{b}_{3} \mathrm{PEU}+\mathrm{b}_{4} \mathrm{PUF}+\mathrm{b}_{5} \mathrm{PCN}+\mathrm{Ut}_{\mathrm{t}}-\mathrm{P} \text { (2) }
$$

$b_{1}-b_{5}=$ Coefficients to be estimated

$\mathrm{U}_{\mathrm{t}}=$ Error term

The relationship between the variables of the study was analyzed using multiple Regression analysis. The hypotheses formulated will be tested by the probability values of the estimates.

\subsection{Results and Discussion}

Table 1: Statistical Significance of the model ANOVA ${ }^{a}$

\begin{tabular}{|cc|c|c|c|c|c|}
\hline Model & $\begin{array}{c}\text { Sum of } \\
\text { Squares }\end{array}$ & df & $\begin{array}{c}\text { Mean } \\
\text { Square }\end{array}$ & F & Sig. \\
\hline & Regression & 353.549 & 5 & 30.710 & .488 & $.003^{\mathrm{b}}$ \\
1 & $\begin{array}{c}\text { Residual } \\
\text { Total }\end{array}$ & 4836.451 & 45 & 109.919 & & \\
& 4990.000 & 50 & & & \\
\hline
\end{tabular}

a. Dependent Variable: CBHV

b. Predictors: (Constant), PCN, PEN, PRK, PEU, PUF

The result of the statistical significance of the model is presented in Table 1. The F- ratio in the ANOVA table above tests whether the overall regression model is a good fit for the data. The table shows that the independent variables statistically significantly predict the dependent variable $\mathrm{F}(5,45)=0.488, \quad p=0.003^{\mathrm{b}}$ (i.e., the regression model is a good fit of the data) 
Table 2: Regression Coefficient

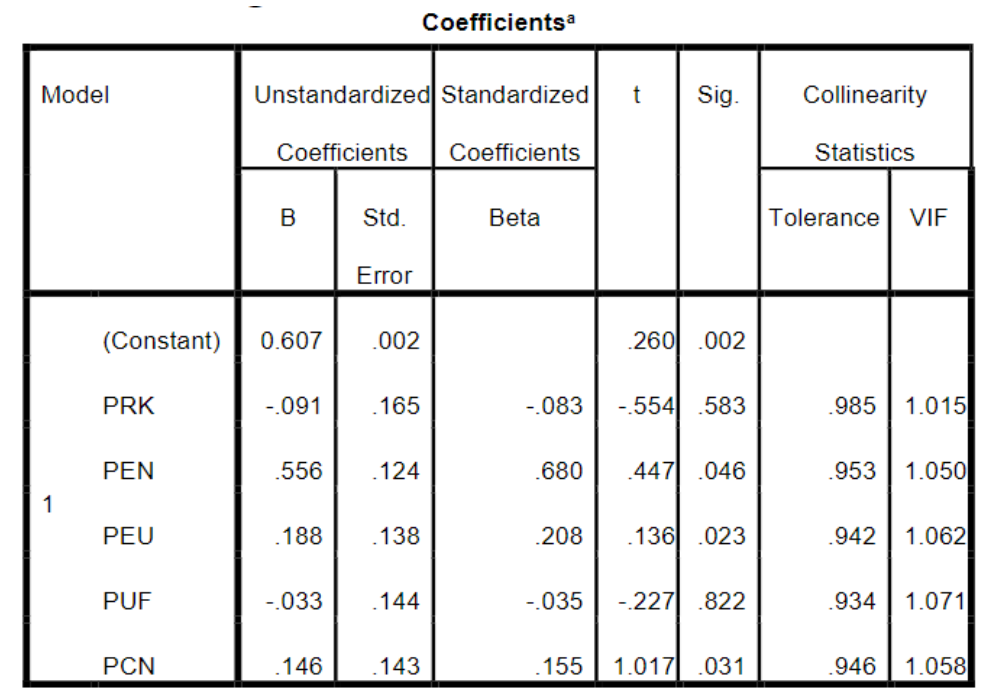

Source: Researcher's Computation

The result of the multiple regression as shown in Table 2 show that a negative relationship exist between perceived risk on consumer (PRK) and consumer buying behavior of electronic products in the north central zone of Nigeria (CBHV) and the relationship is not statistically significant $(p>0.05)$ and in line with a priori expectation. This means that a unit increases in perceived risk on consumer (PRK) will result to a corresponding decrease in the consumer buying behavior of electronic products in the north central zone of Nigeria (CBHV) by margin of $8.3 \%$. Using the probability value of the estimate, $p(\mathrm{~b} 1)>$ critical value at 0.05 confidence level. Thus, we accept the null hypothesis. That is, we accept that the estimate b1 is statistically significant at the 5\% level of significance. This implies that perceived risk has no significant effect on consumer buying behaviour of electronic products in north central zone of Nigeria.

This finding is contrary to that of Jarvenpaa, Tractinsky, and Vitale, (2000) who tested a model of consumer attitude towards specific web base stores in which perceptions of the

store's reputation and size were assumed to affect consumer trust of the retailer. The result indicated that consumers' perceived risks associated with online shopping have a critical effect on their decision making. Many online purchasers have been said to ascertain that they would not shop on a particular website next time if they had an unpleasant experience with it. On the web, shopping enjoyment is positively and significantly related both to attitudes and intentions toward shopping on the web (Chaffey, Ellis and Chadwick, 2012). The negative effect of as shown by this result is a reflection of customers perception and experience in online marketing and shopping. However, consumers behaviour according to this result seems not to be affected even in presence of the perceived risk.

A positive relationship exists between perceived enjoyment (PEN) and consumer buying behavior of electronic products in the north central zone of Nigeria (CBHV) and the relationship is statistically significant $(p<0.05)$ and in line with $a$ priori expectation. This means that a unit increases in perceived enjoyment (PEN) will result to a corresponding increase in the consumer buying behavior of electronic products in the north central zone of Nigeria (CBHV) by margin of $68.0 \%$. Using the probability value of the estimate, $p(\mathrm{~b} 2)<$ critical value at 0.05 confidence level. Thus, we reject the null hypothesis. That is, we accept that the estimate b2 is statistically significant at the $5 \%$ level of significance. This implies that perceived enjoyment has a significant effect on consumer buying behaviour of electronic products in the north central zone Nigeria

This finding is in line with that of Rogers (2003) who concluded that Online shopping features can be either consumers' perceptions of functional and utilitarian dimensions, like "ease of use" and "usefulness", or their perceptions of emotional and hedonic dimensions like "enjoyment by including both utilitarian and hedonic dimensions, aspects from the information systems or technology literature.

Perceived ease of use (PEU) was positively related to consumer buying behavior of electronic products in the north central zone of Nigeria $(\mathrm{CBHV})$ and the relationship is statistically significant $(p<0.05)$ and in line with a priori expectation. This means that a unit increases in perceived ease of use (PEU) will result to a corresponding increase in the consumer buying behavior of electronic products in the north central zone of Nigeria (CBHV) by margin of $20.8 \%$. Using the probability value of the estimate, $p$ (b3) < critical value at 0.05 confidence level. Thus, we reject the null hypothesis. That is, we accept that the estimate b3 is statistically significant at the 5\% level of significance. This implies that perceived ease of use has a significant effect on consumer buying behaviour of electronic products in the north central zone Nigeria.

This finding is in tandem with Chen (2009) who found that perceived ease of use (PEOU) and trust are essential antecedents in determining online consumer behavior through behavioral attitude and perceived behavioral control. Perceived usefulness (PUF) was negatively related to consumer buying behavior of electronic products in the north central zone of Nigeria (CBHV) and the relationship is not statistically significant $(p>0.05)$ and not in line with a priori expectation.

This means that a unit increases in Perceived usefulness (PUF) will result to a corresponding decrease in the consumer 
buying behavior of electronic products in the north central zone of Nigeria (CBHV) by margin of $3.5 \%$. Using the probability value of the estimate, $p$ (b4) > critical value at 0.05 confidence level. Thus, we accept the null hypothesis. That is, we accept that the estimate b4 is not statistically significant at the 5\% level of significance. This implies that perceived usefulness has no significant effect on consumer buying behaviour on electronic products in the north central zone Nigeria. This finding is contrary to that of Weng and Ding, (2012), who examined the relationship between PEOU, PU, attitude towards online shopping, and consumers' intention to shop online.

The result of the multiple regression as shown in Table 2, a positive relationship exist between perceived convenience $(\mathrm{PCN})$ and consumer buying behavior of electronic products in the north central zone of Nigeria $(\mathrm{CBHV})$ and the relationship is statistically significant $(p<0.05)$ and in line with a priori expectation. This means that a unit increases in perceived convenience (PCN) will result to a corresponding increase in the consumer buying behavior of electronic products in the north central zone of Nigeria (CBHV) by margin of $15.5 \%$. Using the probability value of the estimate, $p$ (b5) < critical value at 0.05 confidence level. Thus, we reject the null hypothesis. That is, we accept that the estimate b5 is statistically significant at the $5 \%$ level of significance. This implies that perceived convenience has a significant effect on consumer buying behaviour of electronic products in the north central zone of Nigeria.

This finding is in line with the submissions of Adil (2013) on consumer behavior towards online shopping of electronics in Pakistan. The study found that price, time saving and convenience were identified as important factors which lead to certain buying behavior in online shopping.

\subsection{Conclusion and Recommendations \\ Conclusion}

From the research carried out, it has been revealed that some people do not trust online shopping fully because of factors such as; challenge of delivery time frame, quality of products, inadequate internet connection and card payment problem. Also, the literacy level of many Nigerians towards online shopping is relatively low as many of them do not understand online shopping procedures and still prefer traditional shopping. With the overall survey and research result, we come to the conclusion that the independent e-marketing variables such as perceived enjoyment, perceived ease of use and perceived convenience are positively relating to consumer buying behaviour and that is why the null hypotheses was rejected in this empirical research work. Survey statistics shows that the growth of e-marketing has rapidly increase since past few years. The regression analysis clearly shows that perceived enjoyment, perceived ease of use and perceived convenience plays an important role in the consumer buying behaviour in the study area.

The study has shown that today's business is totally depending on online buying and selling so the companies for selling online products are relaying on E-marketing, advertising, promotion of their product throughout the world. That is why e- marketing become a key for success for online or global business. E-marketing has reached to the point where it become compulsory for companies to adopt it if they want to stay in the business world. With the use of e-marketing, companies market their product or services throughout the world.

\section{Recommendations}

Based on the findings of the study the following recommendations are made:

1. The perceived risk associated with online shopping can be mitigated if the National Assembly as a matter of urgency, make an enactment of e-commerce law a priority. When this happens, the country will enjoy the benefits of a secure and regulated online commercial environment thereby winning public trust. In this regard, online business operators should be registered and licensed before operating in the country or having a liaison office in Nigeria. This will go a long way in checking the excesses of online fraudsters.

2. Owners of online marketing platform should ensure that they make their website dynamic and user friendly so as to attract customers who will derive comfort in engaging on carrying out their transactions from the comfort of their homes.

3. E-commerce portals/marketers should provide a user-friendly platform. The online marketing system should be easy to use requiring less effort on the part of consumer and thereby increases the likelihood of consumer buying behaviour. This is because an application perceived to be easier to use than another is more likely to be accepted by users.

4. For the online marketing to be considered useful, online marketers should create a delivery model which guarantees that orders made get delivered within few hours or the same day an order is made. Also, online business operators should create an avenue for speedy resolution of customers' complaints. When this is done, customers will see the usefulness of this mode of shopping to the conventional one.

5. Online marketers should improve the various aspects of their marketing features such as screen design, feedback and resolution of transaction error withcustomers as this will have a great influence on the acceptance of emarketing service by customers. The convenience that this brings to online shoppers will help to increase their buying behaviour and repeat purchase.

\section{References}

[1].Adil, B. (2013). Consumer Behavior Towards Online Shopping of Electronics in Pakistan. Thesis on InternationalMarketing Management in Seinäjoki University of Applied Sciences.

[2].Ajzen, I. (1991). "The T heory of Planned Behavior", Organizational Behavior and Human.

[3].Asoto, A. (2010). Online Advertising in Nigeria: Overview of Trends, Challenges, and Benefits, Retrieved from: asotoadeola.com on 09/1/2018. 
[4].Bisdee, D., (2007). Consumer Attitudes Review. Office of Fair Trading, June, 1-147.

[5].Buton-Jones, A., \& Hubona, G. S. (2005). Individual Differences and Usage Behaviour: Revisiting a Technology Acceptance Model Assumption. The DATA BASE for Advances in Information Systems, 36(2), 58-77.

[6].Chen (2009). Online Consumer Behavior: An Empirical Study Based on Theory of Planned Behavior" Extends Theory of Planned Behavior (TPB) International Journal of Information Research and Review Vol. 03, Issue, 12, pp. 3385-3387.

[7].Cheung, M.K et al. (2005). Critical Review of Online Consumer Behavior: Empirical Research; Journal of Electronic Commerce in Organizations no.3(4):p1-19 Retrieved on 20/3/2018.

[8].Chiang, K. and Dholakia, R (2003) "Factors Driving Consumer Intention to Shop Online: An Empirical Investigation", Journal of Consumer Psychology, Vol. 13, pp.177-183.

[9].Childers, T. L., Carr, C. L., Peck, J., \& Carson, S. (2001). $\quad$ Hedonic and Utilitarian Motivations for Online Retail Shopping Behaviour. Journal of Retailing, 77(4):511-535. http://dx.doi.org/10.1016/S00224359(01)00056-2.

[10]. Cook, A.J., Kerr, G.N., and Moore, K. (2002). "Attitude and Intentions Towards Purchasing GM F ood", Journal of Economic Psychology, vol. 23, pp 557-572. Retrieved on 3/3/2018 from

[11]. https://econpapers.repec.org/RePEc:e ee:joepsy:v:23:y:2002:i:5:p:557-572.

[12]. Decision Processes, Vol. 50p, pp. 179-211. Retrieve from doi:10.1016/0749- 5978(91)90020-T on 09/1/2018

[13]. Dellarocas, C. (2003). The Digitization of Word-of-Mouth: Promise and Challenges of Online Feedback Mechanisms. Management Science, 49(10):1407-1424.

[14]. Dipti, J., Sonia, G., and Shipra, B., (2014). Consumer Behavior towards Online Shopping: An Empirical Study from Delhi: IOSR Journal of Business and Management Retrieved from (IOSR-JBM) e-ISSN: 2278-487X, pISSN:

[15]. 2319-7668.Volume 16, Issue 9.Ver. IV (Sep. 2014), PP 65-72. Retrieved from www.iosrjournals.org on 3/4/2018.

[16]. Eastlick, M. Liu, M. (1999). The influence of store attitudes and other nonstore shopping patterns on patronage of television shopping programs. Journal of Direct Marketing Banner. Retrieved on 20/4/2018from https://doi.org/10.1002/(SICI)1522- 7138(199722)11:3<14::AID- DIR4>3.0.CO;2-\#

[17]. Evans, D. S. (2009). The Online Advertising Industry: Economics, Evolution, and Privacy. Journal of Economic Perspectives, 23(3), 37-60.

[18]. Farquhar, J.D. \& Rowley, J. (2009). Convenience: A services perspective. Article in Marketing Theory 9(4):425438. November 2009 with 1,526. Retrieved on 20/4/2018 from DOI: 10.1177/1470593109346894.

[19]. Fishbein, M., and Ajzen, I. (1975). "Belief, Attitude, Intention and Behavior: An Introduction to Theory and Research",Addison-Wesley, Reading, MA.

[20]. George, J.F. (2004). "The T heory of Planned Behavior and Internet Purchasing", Internet Research, Vol. 14, no. 3, pp. 198-212. Retrieved on 20/3/2018 from

[21]. http://www.scirp.org/(S(vtj3fa45qm1 ean45vvffcz55))/reference/Reference sPapers.aspx?ReferenceID=1593636

[22]. Grimsley, S. (2015) - What is consumer buying behaviour? - Definition, Types and Quiz. Retrieved on 20/1/2018 from www.study.com

[23]. Hoffman, D. \& Novak , T. (2000). How to acquire customers on the Web. Harvard Business Review. May-June 2000. 179-188.

[24]. Jadhav, V., \& Khanna, M. ( 2016). Factors Influencing Online Buying Behavior of College Students: A Qualitative Analysis. The Qualitative Report, 21(1), 1-15. Retrieved from http://nsuworks.nova.edu/tqr/vol21/ iss1/1.

[25]. Jenyo, G. K. and Soyoye, K. M. (2015). Online Marketing and Consumer Purchase Behavior: A Study of Nigeria Firms. British Journal of Marketing Studies. Publish by European Centre of Research Training and Development UK (www.eajournals.org).

[26]. Kardes, F.R. (2002) Consumer Behavior and Managerial Decision Making (2nd Edition). Prentice Hall; 2 edition.

[27]. Khalifa, M. and Limayem, Moez (2003). Drivers of Internet shopping, Communications of the ACM, 46 (12), pp. 233-239.

[28]. Kim, J. (2004). Understanding Consumers Shopping and Purchasing Behaviours; Department of Apparel Merchandising and Design, Research for Degree of Philosophy, Faculty of Oklahoma State University.

[29]. Kuester, Sabine (2012). MKT 301:

[30]. Strategic Marketing \& Marketing in Specific Industry Contexts, University of Mannheim, p-110.

[31]. Kunz, M. (1997). Online Customers: Identifying store, product and consumer attributes which influence shopping on the Internet. $\mathrm{PhD}$ Dissertation. Retrieved on 20/2/2018 from https://www.researchgate.net/publicati on/34911758.

[32]. Leyiaro, L. (2015). Factors Influencing Online Buying Behavioral of Geothermal Development Company employees in Nakuru Town, Kenya. A Research Project Requirement for the Award of the Degree of Master of Arts in Project Planningand Management of the University of Nairobi.

[33]. Li, N. and Zhang, P. (2002). "Consumer Online Shopping Attitudes and Behavior: An Assessment Of Research". Eighth Americas Conference on Information Systems. Kim, J. Fiore, A. and Lee, H. (2007). Retrieved on 21/3/2018 from http://melody.syr.edu/pzhang/publicati ons/AMCIS02_Li Zhang.pdf.

[34]. Limayem, M., Khalifa, M., and Frini, A. (2000). "What Makes Consumers Buy from Internet? A Longitudinal Study of Online Shopping", IEEE Transactions on Systems, Man, And Cybernetics, vol. 30, no.4, pp. 421-432. 
Retrieved 21/3/2018.From https://pdfs.semanticscholar.org/176d/ 77bfdf55a180926153fc1da065b60203 3600.pdf.

[35]. Malhotra, N. K. (2004). Marketing research: An applied Orientation (4 ${ }^{\text {th }}$ ed.). New Delhi, India: Dorling Kindersley Pvt. Ltd.

[36]. Mangold, W. G. \& Faulds, D. J. (2009). Social Media: The New Hybrid Element of the Promotion Mix. Business Horizons, 52(4), 357-365.

[37]. McCloskey, D. (2004). Evaluating electronic commerce acceptance with the technology acceptance model. Journal of Computer Information Systems, 44(22), 49- 57.

[38]. Menon, S. and Kahn, B. (2002). Cross- category Effects of Induced Arousal and Pleasure on the Internet Shopping Experience. Journal of Retailing, 78(1), 31-40. Retrieved on 20/2/2018 from http://psycnet.apa.org/record/2002-15150-002.

[39]. Mohammed, A. J. (2016). Online Shopping: An Analysis of Technology Acceptance Model of Jordanian Customers. Retrieved 23/6/2018 from DOI: 10.18843/rwjasc/v7i4(1)/16 DOI URL : http://dx.doi.org/10.18843/rwjasc/v7i4 (1)/16.

[40]. Muhammad, K.B.D, Muhammad, I. and Chaudhary, A.R. (2015). Online Shopping Trends and its Effects on Consumer Buying Behaviour. NG-Journal of Social Development, VOL. 5, No. 1, October 2015. ISSN: 01895958www.arabianjbmr.com/NGJSD_i ndex.php.

[41]. Pavlou, P.A. (2003). "Consumer Acceptance of Electronic Commerce: Integrating Trust and Risk with the Technology Acceptance Model", International Journal of Electronic Commerce, vol. 7, no.3, pp. 101-134. Retrieved on 21/3/2018 from https://www.tandfonline.com/doi/abs/1 0.1080/10864415.2003.11044275.

[42]. Pride, W. M. \& Ferrell, O. C. (2012). Marketing, 2012 Edition. Mason, Ohio: SouthWestern, Cengage Learning.

[43]. Ramus, K. and Nielsen N.A. (2005). "Online Grocery R etailing: What do Consumers think?", Internet Research, vol. 15, no. 3, pp. 335-352. Retrieved on21/3/2018 from https://www.emeraldinsight.com/doi/p df/10.1108/10662240510602726.

[44]. Schiffman, L. \& L. L. Kanuk, L.L. (2002) Consumer Behavior, Eighth Edition. Pearson Education.

[45]. Selamat, Z., Jaffar, N., \& Ong, B. H. (2009).Technology acceptance in Malaysian

[46]. Banking Industry. European Journal of Economics, Finance and Administrative Sciences, 1(17), 143-155. Retrieved from https://www.researchgate.net/publicati on/239587726 on 26/62018.

[47]. Soonyong Bae, Taesik Lee (2010). Gender Differences in Consumers' Perception of Online Consumer Reviews. Retrieved from https://link.springer.com/article/10.100 7/s10660-010-9072-yon 29/7/2018.

[48]. Tarinee, C. (2007). The influential factors on consumers' purchasing decisions in Bangkok pet retailing business. Master of Business Administration in Management, Shinawatra University in Partial Fulfillment of the Requirements for the Degree of Master of Business Administration in Management.

[49]. Taylor, S.L. and Cosenza, R.M. (2002), "Profiling later aged female teens: mall shopping behavior and clothing choice. Journal of Consumer Marketing, 19(5): 393-408. Retrieved from https://www.researchgate.net/publicatio $n / 228627458$.

[50]. Teo, T. S. H. (2002). "Attitude Towards Online Shopping and the Internet", Behavior \& Information Technology, vol. 21, no. 4, pp. 259-271. Retrieved on 20/2/2018 from http://citeseerx.ist.psu.edu/viewdoc/do wnload?doi=10.1.1.472.6762\&rep=re pl\&type $=p d f$

[51]. Turban, E., King, D., Lee, J., Liang, T.-P. \& Turban, D. C. (2010). Electronic Commerce 2010, A Managerial Perspective. New Jersey: Prentice Hall.

[52]. Ugonna, A., Okolo, O., Nebo, N., and Ojieze, J. (2017). Effects of Online Marketing on the Behaviour of Consumers in Selected Online Companies in Owerri, Imo State - Nigeria. International Journal of Business and Management Invention ISSN (Online): 2319 - 8028, ISSN (Print): 2319 - 801X www.ijbmi.org || Volume 6 Issue 6 || June. 2017 || PP-32-43. Retrieved 20/2/2018.

[53]. Venkat, V. (2015). "A theoretical Extension of the Technology Acceptance Model: Four Longitudinal Field Studies," Management Science, 46. 186-204.

[54]. Wang, Cheng Lu, Yue Zhang, Li Richard Ye, and Dat-Dao Nguyen (2005). "Subscription to fee-based online services: what makes consumer pay for online content?" Journal of Electronic Commerce Research 6, no. 4 (2005): 304.

[55]. Weng, M.L. and Ding, H.T. (2012). E- shopping: An Analysis of the Technology Acceptance Model Accepted: February 14, 2012 Published: April 1, 2012. Retrieved 23/6/2018 from doi:10.5539/mas.v6n4p49.

[56]. URL: http://dx.doi.org/10.5539/mas.v6n4p4 9 Yoon, D., Choi, S. M. \& Sohn, D. (2008).Building Customer Relationship in an Electronic Age: The Role of Interactivity of E-Commerce Web Sites. Psychology \& Marketing, 25(7), 602-618.

[57]. Zhu, F. \& Zhang, X. (2010). Impact of Online Consumer Reviews on Sales: The Moderating Role of Product and Consumer Characteristics. Journal of Marketing, vol. 74, 133-148. 